\title{
From war economy to peace economy?
}

\section{Draft}

by Jonathan Goodhand, SOAS, University of London

\section{Introduction}

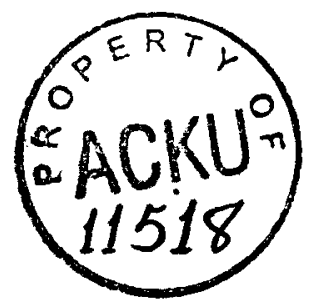

This paper aims to provide an analytical framework for understanding the contemporary dimensions of the Afghan war economy and the implications for current efforts to build peace." "Winning the peace" will depend in no small part on international and domestic efforts to transform the war economy into a peace economy.

Key points emphasized are:

The dearth of empirically-based research on the war economy. Policies have frequently been based on limited data and questionable assumptions. The paucity of quantitative and qualitative data on the war economy has held back efforts to respond to the problem. Afghanistan has been an "orphaned conflict" for more than a decade - this applies not only to earlier international attempts to contain rather than resolve the conflict, but also to the lack of serious research inside the country. ${ }^{2}$ This paper $^{3}$ draws upon a combination of primary research and secondary sources, however hard data is difficult to come by and frequently unreliable. The rural economy remains to a large extent statistically unknown. ${ }^{-}$ Emerging policy is based therefore upon a limited understanding of the processes at work. There is an urgent need to "skill up" in terms of improving understanding through an investment in research and analysis.

The regional dimensions of the war economy: Afghanistan is part of a regional conflict complex, in other words a "bad neighborhood" which connects other latent and open conflicts within the region, including Kashmir, Tajikistan and the Ferghana Valley. According to Peter Wallensteen, the Central Asia conflict complex is one of 16 regionalized violent conflicts to have occurred since the Cold War. ${ }^{5}$ The outer borders of this complex are unclear but for the purpose of this paper the core Central Asian regional complex is defined as Afghanistan and its neighboring countries Pakistan, Iran and all the Central Asian states, i.e. Tajikistan, Uzbekistan, Turkmenistan, Kyrgyzstan and Kazakhstan. The region includes close to 300 million people. Beyond this core regional complex, China, India, Kashmir, the Caucasus and the Middle East, particularly Saudi Arabia, are also significant. The political, religious and socioeconomic networks within this wider regional complex also connect with various conflict stakeholders inside Afghanistan. Afghanistan cannot be disentangled from the wider regional complex(es). A state-centered approach to peacebuilding will fail to meet the more fundamental challenge of transforming inter-state and non-state relations, institutions and economic structures at the regional level.

The limitations of 'greed' based analysis: While international representations of the conflict have varied over time and between different actors, a dominant discourse emerged in the 1990s which drew heavily on the writings of those analysing collapsed state, warlord

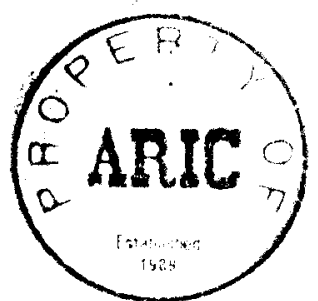


conflicts in Africa. This "model" tended to place the war economy at the center of the conflict dynamic. It was assumed that the war had mutated from a Cold War "holy war" driven largely by ideological motives into a regionalized civil war in which economic agendas were the primary driving force. In other words, to borrow David Keen's phrase, war had become "the pursuit of economics by other means." One can question two strands in this representation of the conflict. First, the tendency to "internalize" the conflict leads us dangerously towards the idea that Afghanistan somehow can be treated as though it were an isolation ward. However, our analysis of the war economy highlights its global and regiona! dimensions. Conceptualizing the war economy as purely or even primarily an internal phenomenon may be politically expedient - since attention is deflected away from the role of international and regional players in causing or fueling this economy - but it is unhelpful in terms of developing robust and intelligent policies. Second, the view that the war is primarily about "greed" rather than "grievance" is simplistic. The opium and cross-border" smuggling economies enable different groups to wage war, profit, cope or survive. The assumption that all actors are engaged in war because of a rational economic calculation ignores both the political economy and emotional economy of the conflict and may lead to policies which assume that the war economy can be transformed simply by applying economic sticks and carrots. It also tends to encourage a belief that the "illicit" economy can and should somehow be ring-fenced and treated in isolation from the "licit" economy. We will argue that the challenge of "winning the peace" is ineluctably a political one involving the creation of institutions that transform incentive systems. And far from criminalizing the profiteers, attempts will need to be made to encourage them to invest their accumulated profits in the licit economy. Similarly a more nuanced analysis of warlords, their capacities and their incentives systems is required. Some for instance may have political ambitions and perhaps could make the transition from warlord to statesman. Opportunities will be missed if they are viewed only as conflict entrepreneurs or economic agents.

The persistence of the war economy into "peacetime" conditions. The "post-conflic1" tag can be questioned. The political basis for peace is still uncertain with large sections of the population sidelined by the post-Taliban order. Clearly peace would represent at "regional public good." But if the spoils of peace go only to a small group of "shareholders" there is unlikely to be a sustainable peace. The beneficiaries of war economies are likely to continue resisting central interference and control.

\section{War, Shadow, and Coping Economies in Afghanistan}

The term "war economy" is commonly used to include all economic activities legal of illegal carried out in wartine. Here we use the term more narrowly to distinguish it from other types of economy that emerge in wartime conditions. Broadly we can identify three types of economy - the war, shadow and coping economies - that enable different groups to wage war, profit, cope or survive. Each has its own dynamic and patterns of change. The main characteristics of these three economies are:

- War economy. The war economy includes both the production, mobilization and allocation of economic resources to sustain a conflict and economic strategies of war aimed at the deliberate disempowerment of specific groups. ${ }^{7}$ Whereas the former involves the 
generation of resources to wage war, the later involves the destruction of resources 10 undermine the ability of opposing groups to wage war.

- Shadow economy. The terms "black" or "illicit" economies are problematic and valueladen, particularly in contexts where there is a legal vacuum. ${ }^{8}$ But we seek here to highlight the distinction between those whose objective is to wage war and those who aim to profit while in practice these categories may overlap this need not be the case. In most conflicts there are actors who profit from conflict. However, unlike the conflict entrepreneur, the economic entrepreneur operating as part of a shadow economy may have an interest in peace - if peace can enable the maintenance or increase of profits.

- Coping economy. The term coping economy refers to population groups that are coping (i.e. using their asset-base non-erosively) or surviving (i.e. using their asset based erosively). These categories are not static and change over time according to the influence of changing political regimes and various external shocks. While direct agricultural production tends to remain an important part of this economy, households tend to diversify into a range of onfarm and off-farm activities to cope or survive.

Table 4.1 presents a typology of these three economies as applied to the case of Afghanistan. While in practice the distinctions among them are not as neat and clear as the table implies, the typology is useful as an analytical framework to understand the particular characteristics of war, and peace, economies in that country.

Table 4.1 Afghanistan: Economies, Actors, Motives and Activities 


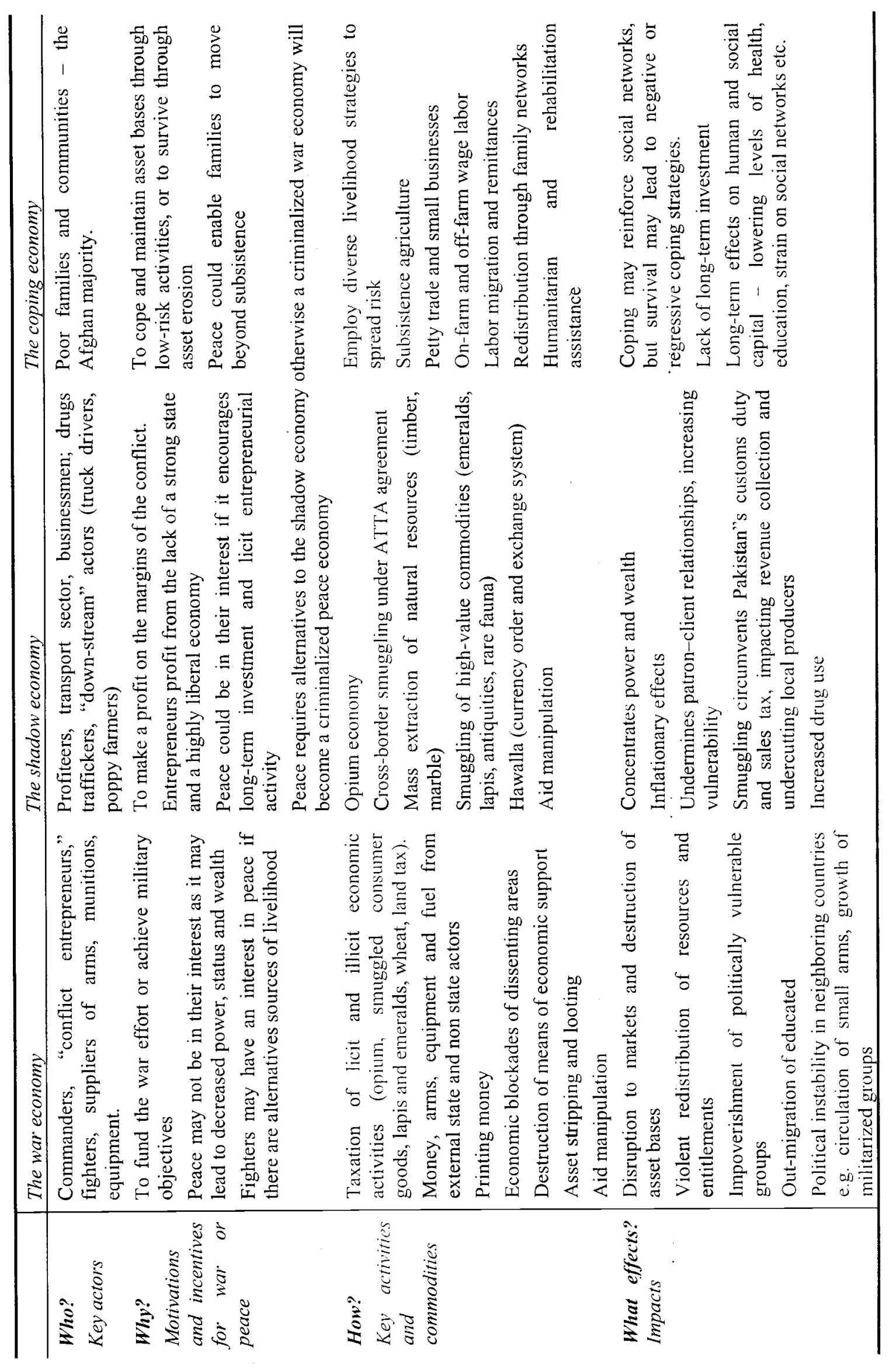


롱

롤

䆑

을 언

포 를

氙

छ

芯 $\cdot \frac{n}{5}$

종 뭉

₹

ఫี

胥

ठ

형

焉

ฮ

घ

은

गृ

․

蛋

$\ddot{8}$

现

요 


\section{Contemporary Dimensions of the Afghan Political Economy}

The historical development of the war economy has been dealt with elsewhere ${ }^{9}$ In the following section we attempt to map out some of contemporary features of the Afghan political economy. While conflict has led to profound transformations there are also important continuities with the past. The current political economy builds upon much older patterns of human organization and interaction. For instance the drugs, smuggling and religious networks draw upon pre-war social networks based on qawm ${ }^{l()}$ and tribal loyalties. Warlords and profiteers play new games by old rules, mobilizing the "economy" of affection", just as other rulers have throughout Afghan history.

The war and shadow economies have persisted and in some respects been re-invigorated in the post-Taliban order. Afghanistan is reverting to the pattern of governance of the early 1990 s, with regional warlords re-establishing control over personal fiefdoms. While warlords control the smuggling and drugs trades, which in turn fund their own private militias, there are few incentives for engaging with the embryonic central state. In addition, many of the international/regional dimensions of the Afghan political economy are still present.

\section{$\underline{\text { War Economy }}$}

While international attention has tended to focus on drugs in relatiọn to the war economy it is important to remember that external resource flows including arms, ammunition, fuel and financial support from state and non-state actors in the region have probably been more significant than internally generated revenue. During the 1980s, Afghanistan received more than 3 million tonnes of military supplies making the country the world's largest per capita arms recipient. There are estimated to be around 10 million small arms and light weapons (SALW) currently in circulation. ${ }^{11}$

The war economy needs to be located within a global and regional framework. Strategies of reproduction adopted by states play themselves out beyond national borders. Pakistan's pursuit of strategic depth in relation to India for instance has had profound implications in terms of Afghanistan's political economy. There have also been regional "blow-back" effects, most seriously in Uzbekistan - where the Islamic Movement of Uzbekistan challenges the legitimacy of the state - and in Pakistan where armed protoTaliban groups have caused growing instability and may threaten the long-term security of the state. ${ }^{12}$

The regional dimensions of the war economy appear to be deeply entrenched and have persisted beyond the Taliban phase of the conflict. In addition, warring groups continue to develop and utilize extremely sophisticated ways of operating in and exploiting regional and global economies - Duffield's description of warlords who "act locally, but think globally" is an apt one. ${ }^{13}$ These conflict entrepreneurs have developed their "asset portfolios" by building up a command over the means of violence and developing links to global markets. As a result, warlords have access to sophisticated weaponry and lootable resources while fighters can be recruited for one meal a day.

Warring groups have always depended on external support from international and regional actors and few have ever been purely self-financing. General Rashid Dostam, a 
UF commander based in Maza-e-Sharif, for instance, is currently guarded by a close protection unit seconded from the Special Forces of Uzbekistan. There are indications that elements within Pakistan's ISI are supporting Hekmatiya's Hezb-i Islami and Taliban forces. Russia continues to provide arms to the Shuri-nizar in the north-east ${ }^{14}$.

In addition, a range of strategies have been utilized to generate resources internally, including pillage, protection money, controlling trade, land and markets, appropriating aid and the smuggling of goods, people and drugs. Moreover, various economic strategies of war have been pursued, including the economic blockade of Hazarajat by the Taliban, their scorched earth tactics on the Shamoli Plains, the deliberate destruction of rural infrastructure by the Soviets and more random and opportunistic forms of violence and criminality (as occurred in Kabul and Kandahar during the early 1990s). While both organized and random violence lead to processes of dispossession and the violent redistribution of entitlements, "roving" rather than "stationary" bandits have had the most damaging effects on infrastructure and markets. The loss of a monopoly of violence in a particular locale creates incentives for more predatory behavior. For instance in 1998 when fighting between Dostam and a rival general broke out in Mazar-i-shariff, trade with Uzbekistan was disrupted, leading to greater militia extortion of the rural population. ${ }^{15}$ There was hoarding of food by the army and increased looting and selling of booty in Central Asian markets.

The opium and smuggling economies also continue to play an important role in sustaining the war economy. Reports suggest that in Kandahar, customs revenues generate around $\$ 18$ million per annum while as much as $\$ 50$ million is generated in Herat $^{16}$. Not surprisingly, current struggles between warlords are thought to be related to control over trade routes and markets. For instance clashes between Ismael Khan and Gul Afgha in the West are at least partly over control of lucrative trade routes coming through that part of the country. In Nangarhar clashes in the wake of the assassination of Abdul Qadir one of the vice presidents of the Transitional Administration in July 2002 have been linked to control of trade routes for smuggling heroin and other goods into Pakistan. ${ }^{17}$

According to Johnson et al., one year after the signing of the Bonn Agreement there remained around 70,000 men in regular forces and another 100,000 irregular militia members. ${ }^{18}$ There are still strong bottom-up incentives to engage in violence. The demand for protection and the lack of alternative livelihoods remain powerful motivations to join military groups. As Hirshleifer notes, the poor may have a comparative advantage in violence as they have less to lose.$^{19}$ As a result, warlords will likely continue to play an important role given the strong demand for security.

\section{Shadow Economy}

While the interests of the conflict entrepreneur and the profiteer may often coincide, this has not always been the case. For instance, while transport merchants may have had extremely close links to the Taliban, their interests did not always coincide with those of the front-line commanders. In fact at certain times their objectives have worked against one another. For example profiteers undermined the Taliban's economic blockade of Hazarajat by keeping trading networks open. Similarly, in 1995 the Taliban offensive on 
Herat was bankrolled by Pakistani traders looking to capture the trade routes and markets in the West, but this was against the advice of Pakistani military advisers ${ }^{20}$.

Clearly however, markets and profits are regulated by access to political power and the means of violence. While in the 1950s the Afghan merchant class were politically weak and heavily taxed, by the 1980s and 1990s, the transport sectors in the Pakistani cities of Peshawar and Quetta were an important political force, due largely to their close ties with military groups. Markets in the East have become increasingly articulated towards Pakistan. Borders have become areas of high risk but high opportunity where deals are cut between profiteers and conflict entrepreneurs. As poppy moves from farmers' fields across borders there is a five-fold increase in price. The largest profits are made smuggling across-borders, a trade that is dominated in the south by Baluchi traffickers with Afghan, Iranian and Pakistani passports. Beyond borders, prices increase again. For instance in the Tehran wholesale market there is a six-fold increase in prices from Pakistan's border areas. Opiate trafficking profits in the countries neighboring Afghanistan amounted to some $\$ 4$ billion in 2002 , of which $\$ 2.2$ billion went to criminal groups in Central Asia. ${ }^{21}$

The shadow economy has led to a growing differentiation among population groups. For example, farmers with land and capital lease out their land for poppy cultivation and are able to accumulate assets while landless farmers who have no other sources of credit are pushed further into debt. ${ }^{22}$ According to UNODC there were approximately 15,000 opium traders in the country in the late 1990s (about one trader per 13 farmers). Profits from the trade have been invested in conspicuous consumption and have had inflationary impacts in core growing areas. ${ }^{23}$ Violent conflict has destroyed some commodity markets while creating others. In Badakhshan, for example, the livestock trade with Kabul was decimated due to insecurity, but the opium trade with Tajikistan has flourished. The informal economy also plays an important role in shaping formal economies and transborder trade has undermined the economies of Pakistan and other neighboring states. Moreover, while the trading economy has helped mitigate some of the impacts of drought it is not productive in the sense that there is no long-term investment in infrastructure or industries. Entrepreneurs gravitate towards quick-return activities and the profits are accumulated outside the country. Without a strong state and a legal framework, there are few incentives to make the shift towards longer-term productive activities.

The shadow economy has led to the reconfiguring of regional networks and has had considerable costs for neighboring states. Criminal organizations have beconc embedded in the region and the shadow economy undermines the formal economies of surrounding countries. The open trade regime of Afghanistan compared to the restrictive trade regimes of neighboring countries creates powerful incentives for smuggling. Crossborder smuggling circumvents Pakistan's custom's duties and sales tax with its consequent impacts on revenue collection and the undercutting of local producers. In 1992 the loss in customs revenues to Pakistan was $\$ 87.5$ million, which had risen to $\$ 500$ million in 1995 . $^{24}$ The shadow economy is based upon social solidarity networks within the region. Particularly important have been Pashtun diaspora communities in Dubai and Karachi with their links to Quetta and Kandahar. 
Historical experience shows that wartime capital accumulation is brutal and war is the most common contemporary form of primitive accumulation. Asset portfolios are built upon oppressive working conditions, fear and force. However, the shadow economy may also support processes of actually existing development, something that Chingono describes in Mozambique as being a "barefoot economy" or a vibrant capitalism from below. ${ }^{25}$ Research in Badakshan revealed that in some respects the opium economy has had developmental outcomes although the benefits were unevenly distributed. ${ }^{26}$ There was evidence of accumulation and investment back into the village and the opium trade had kept young men in the area who might otherwise have left. It appeared to have reinforced rather than eroded food security. On the other hand, the opium economy has created new tensions within the village in terms of how wealth was produced and distributed. It created a nouveau riche of the young men involved in the opium trade and the commanders who taxed and controlled it.

\section{Coping Economy}

Overall vulnerability has grown with the gradual erosion of asset bases across groups. Families have either retreated into subsistence or are adversely incorporated into the market through, for instance, laboring in poppy fields or children working in the carpet industry. Labor has become one of Afghanistan's primary exports. Remittances are central to the Afghan economy, and to Afghans living in neighboring countries. Social obligations fuel the remittance economy. Diaspora remittances also increase social differentiation - in general families with relatives in Europe or the Gulf are able to accumulate, while the remittance economy in Pakistan and Iran is more commonly associated with survival. Therefore Afghan households have tended to "stretch" themselves over several countries in the region and mobility has been a key component of coping or survival. ${ }^{27}$

There is a tendency to assume that those involved in poppy farming or the opium trade are either "greedy" entrepreneurs or profit-maximizing farmers. In fact for the majority, involvement in the opium economy is motivated by coping or survival. Afghan families seek to spread risks by diversifying entitlement portfolios - sons migrate to Pakistan, women and children work in the carpet industry, fathers enter share-cropping arrangements to gain access to land to grow poppy and the remaining women and children play an important role in tending the crop since poppy is extremely laborintensive. ${ }^{28}$ Only about $2.6 \%$ of agricultural land is used for cultivation of poppy, but between 3 and 4 million people (about $20 \%$ of the population) were by the end of the 1990 s dependent on poppy for their livelihood ${ }^{29}$

Research in 2003 showed a growing dependency on poppy as a means of survival. ${ }^{30}$ Poppy growing has had an inflationary impact and increased the levels of land rents, marriage costs and borrowing. People were taking increasingly desperate measures to repay debts including absconding, the sale or leasing of long-term productive assets and the early marriage of daughters. Creditors were also using more authoritarian tactics to ensure repayment including kidnapping daughters, confiscation of domestic possessions and compulsory land purchases. Failure to repay debts has become a major source of conflict. An average accumulated debt of $\$ 1,835$ was recorded in the areas researched and in Helmand the average debt was $\$ 3,010$. Farmers anticipated paying off 
debts within a two- to six-year period. Therefore many are locked into the opium economy for several years into the future.

Although agricultural harvests in 2002 improved by as much as $80 \%$, the growth in production has been uneven. Furthermore the return of almost 2 million refugees is likely to have a significant impact on livelihoods and competition for scarce resources. ${ }^{3 .}$ There are reports of conflicts in the North as a result of Pashtun returnees.

\section{The Linkages Between War, Shadow and Coping Economies}

Our schema of the war, shadow and coping economies evidently simplifies reality. In practice there are no clear boundaries among these three economies, and networks have developed with complex overlapping connections. Incentive systems vary at different levels of the commodity chain. For a resource-poor farmer, poppy is part of the coping or survival economy; for the landowner leasing his land or for the opium trader it is part of the shadow economy; and for commanders that tax poppy it is part of the war economy. Opium is simultaneously a conflict good, an "illicit" commodity and a means of survival. Different commodities - such as weapons, money, drugs, consumer goods or food - may travel along the same routes. The sarafi or money changer, is an important node in this network - his services are used by warlords, profiteers, communities and aid agencies.

Conflict resolution approaches tend to assume a clear division between pro-war and pro-peace constituencies or between a criminalized war economy and a licit peace economy. But network war dissolves the conventional distinctions between people, army and government. ${ }^{32}$ The networks which support war cannot easily be separated out and criminalized in relation to the networks that characterize peace. Attempts by the United States to clamp down on the hawalla system for instance, would have a negative effect on the livelihoods of the bulk of the population as well as those of the warlords and profiteers.

In border areas this intermingling and overlapping of various "licit" and "illicit" flows - of arms, drugs, smuggled luxury goods along with wheat, water melons and refugees - is most apparent, though not always visible. These borders are places of opportunity and exploitation. ${ }^{33}$ Borderlands are also places of constant flux as the geography of the conflict ebbs and flows and the policies of neighboring countries change. In Nuristan for example a new infrastructure of roads, hotels and bazaars developed due to the need for secure supply routes for the resistance. ${ }^{34}$ Opium laboratories tend to be located close to borders.

The shadow economy may well promote processes of development - they link remote rural areas to major commercial centers, both regionally and globally, though the benefits of this development are unevenly distributed. The benefits of the drug economy can be seen in the reconstruction of the villages around Kandahar. ${ }^{35}$ These economies also involve complex socio-cultural and political as well as economic organization, in networks of exchange and association. These networks are governed by rules of exchange, codes of conduct, hierarchies of deference and power, ${ }^{36}$ and are reinforced through a series of strategies, including inter-familial marriage (wife-givers and wifctakers), gifts, and partnerships (with family members presenting claims for profit, involvement and opportunity). They are not anarchic and do not depend purely on coercion. Trust and social cohesion are critical. Counter-intuitively, it may be the absence of a state and predictable social relations which engenders greater trust and solidarity at 
the local level. ${ }^{37}$ Interestingly, many Pakistanis use the sarafi system even though there is a functioning formal banking sector - evidently the informal system provides the reliability and predictability lacking in the official economy. It may also be more "propoor" in the sense that the poor are considered by the formal sector to be too risky.

International assistance interacts in various ways with these three economies. Development aid in pre-war Afghanistan contributed to the development of a rentier state and the structural tensions which led to the outbreak of war. During the 1980 s, humanitarian assistance was the non-lethal component of support to the Mujahideen and much of it fed directly into the war economy, with donors being prepared to accept "wastage levels" of up to $40 \%$. Aid has also been a significant factor in the coping and survival economy, as the second largest sector of the "illicit" economy after agriculture. Before 11 September about 25,000 Afghans were employed with aid agencies and the Swedish Committee for Afghanistan, an international solidarity NGO was the largest single employer in the country. In urban areas, particularly Kabul, where there is a large aid-dependent population, humanitarian assistance has been critical to survival. Finally, aid interacts with the shadow economy, particularly in the current context with relatively large injections of resources into Kabul creating a parasitic bubble economy. The US dollar increasingly dominates the money exchanges in the cities whereas the countryside remains in the Afghani or Pakistani rupee zone. ${ }^{38}$ There is an obvious danger of history repeating itself with international assistance exacerbating the underlying tensions and disparities between countryside and city.

There should perhaps be an additional economy in our schema and this might bo termed the "emotional economy." Although it has been rightly argued that war cannot be fought on hopes and hatreds alone, the contention that war is purely about interests rather than passions can be questioned. ${ }^{39}$ The ideas and meanings that people attach to events. institutions, policies and motives are important. To an extent the madrasas from which the Taliban emerged responded to a hunger for social identity. Again, aid interventions may have an important impact on this emotional economy by influencing ideas. relationships, social energy and individual leadership. Education programs and series such as the BBC "New Home, New Life" is a positive example of how aid may engage in the battle for ideas. The perceived legitimacy of aid actors depends to a great extent on how sensitive they are to this "emotional economy."

Finally, in our analysis of the schema we have attempted to highlight the nexus between global markets, capital formation, investment and criminality. In Afghanistan there have been processes of systematic adaptation by elites to changing international and regional conditions. Rather than seeing the war economy as purely a reaction to state failure, one could alternatively conceptualize state collapse as being something that is actively sought after by elites living on the periphery. ${ }^{40}$ Wartime economic activities have involved processes of brutal primitive accumulation which are likely to extend beyond the end of the fighting. A common response of wartime entrepreneurs after a peace settlement has been to shift capital abroad or to continue exploiting "illicit" activities or" high rent market opportunities with little state regulation. Arguably, central authority is needed to break up violent primitive accumulation - and to protect the interests of the poorest and to bring about structural transformation. Simply attempting to ring fence and criminalize the shadow and war economies is likely to have perverse effects. For example, a complete closure of the Afghan-Pakistan border and the cessation of illegal 
trade would create the conditions for a social explosion in several regions of Pakistan -GDP in the North-west Frontier Province fell from 3.3\% in 1981 to 2.2\% in 1998 and cross-border trade is central to the coping and survival strategies of border communities. Similarly, drug policies in the past have tended to put a higher priority on establishing a "security belt" around Afghanistan rather than investing significant resources inside the country to create alternative livelihoods and transform governance structures. Arguably there has been an asymmetrical focus on the supply side rather than addressing the demand in Western countries. With the right combination of (dis)incentives, wartime entrepreneurs who have historically been labeled profiteers, economic criminals or greedy warlords may perhaps also become builders of a basis of longer-term, more legitimate economic success.

\section{Policy Implications}

The final part of this paper involves a short and necessarily selective exploration of some of the key policy challenges for international development donors related to transforming the war economy to peace economy. As President Hamid Karzai has noted. security and development are two sides of the same coin. However, peace agreements often pay limited attention to the question of economic security. In a country in which. according to the World Food Program, more than 6 million people remained vulnerable one year after the fall of the Taliban, this is an important question ${ }^{41}$. A significant peace dividend is required. Furthermore if it only involves a small group of "shareholders" the spoils of peace may end up legitimizing the war.

One of the main challenges with regard to efforts to support the political transition through international assistance is the tension between the desire to support Afghan-led development and the need to channel resources where there is the capacity to spend them. The main source of capacity in terms of relief and reconstruction efforts is the NGO and UN system, who themselves are estimated to employ around 40,000 Afghans. According to the Minister for Rural Development over $90 \%$ of external aid entering Afghanistan has gone through non-state entities. ${ }^{42}$ As has happened elsewhere, the salaries and working conditions offered by international agencies have tended to attract the best-qualified Afghans and in a sense have actively de-capacitated Afghan institutions.

Another, related challenge is the tension between the need for quick impact programs which meet humanitarian needs and counteract the immediate bottom-up incentives to engage in the war and shadow economies, and the need for longer-term support that builds the capacity of the state. Both will have to be pursued simultaneously. However, as with the security transition, short-term imperatives should not undermine longer-term goals. Again, a regional frame of reference is required. The return of about two million refugees strained resources and infrastructure, and in many respects hijacked the development agenda in Afghanistan as resources were allocated to emergency assistance. $^{43}$ A regionally-informed analysis might have led development agencies to think more carefully about the sequencing of return and continuing support for refugees in neighboring countries.

As Von der Schulenberg argues, the West is not necessarily under-investing but mis-investing in Afghanistan and the challenge is largely about how to do more with less. 
Although the UN Special Representative for Afghanistan and head of UNAMA, Lakhdar Brahimi, promised a "light footprint" in terms of international presence, based on lessons learned from East Timor, in practice there has been an extremely heavy footprint in Kabul and an extremely light - to the extent of being barely visible - footprint outside the capital. This has generated negative views towards the international community among the Afghan population, and is likely to have significant political effects particularly in the Pashtun south which feels excluded by the political settlement and.has arguably received less in the way of reconstruction and development aid. Policies to eradicate drugs also play into this dynamic since the predominantly Pashtun south and east are the main opium-growing areas. The UK government, which has taken a lead on this issue, has set a target of a $70 \%$ reduction in opium poppy crops by 2008 and $100 \%$ by 2013 . However. unless there are serious efforts to invest in poppy growing regions, eradication measures, as last year demonstrated, will exacerbate underlying political tensions and conflicts.

Attracting back educated Afghans is also likely to be a central challenge and this depends largely on the provision of basic security and the state's ability to mobilize and redistribute resources. A decentralized and criminalized economy is no basis for genuine social and political legitimacy, let alone poverty reduction and social progress. However. as already emphasized, attempting to protect the shadow economy will be counterproductive. The right incentives may encourage profiteers to invest in legitimate business. For example, many businessmen involved in the hawalla system could potentially make the transition into the formal banking sector with the right kind of support and institutional framework.

The shadow economy has thrived because of Afghanistan's geographic position and transnational social networks. However, these comparative advantages could bo utilized in relation to the licit economy. Afghanistan has the potential to become a hub for regional trade because of its central location, although the pre-conditions for this are regional stability, roads and communication networks as well as a strong central government. A massive investment in infrastructure concentrated in high export potential will be required. At one time, for example, Afghanistan provided $40 \%$ of the world's raisin market. There is clearly great potential for developing regional cooperation in are $₫ s$ such as water, power and trade. Forms of intra-regional collaboration are already being developed or explored. For instance, Iran and Pakistan both made aid commitments at Tokyo and have provided assistance in areas such as humanitarian aid and infrastructure programs. Pipeline construction talks between Pakistan, Turkmenistan and Afghanistan have also recommenced.

As emphasized earlier in this section, development assistance also must be directed beyond Afghanistan's borders. The problems of failing states, chronic poverty and social exclusion are regional phenomena and need to be addressed as such. More thought needs to be given as to how development policies can complement efforts to build human security. While a number of the smaller bilateral donors such as Switzerland and the UK have explored approaches which seek to do this, the IFIs have to a large extent been "conflict blind." Privatization policies in particular have accentuated tensions and played into greed and grievance dynamics by providing opportunities for elite enrichment while stripping away forms of social protection. An attempt by the European Bank for Reconstruction and Development to link loans to improvements in 
human rights in Uzbekistan may be evidence of a more politically informed approach emerging.

\section{Conclusions}

Based on our analysis four general points stand out as guiding principles for international policy.

First, as already highlighted, the historical and contextual understanding of international actors has often been a constraint in the past and is likely to be even more so now, given the influx of new actors with no track record in the country. Afghanistan has fallen off the research map for more than two decades and to an extent understanding is stuck at pre-war levels. Given Afghanistan's diversity - every mountain valley has its own micro climate - the need for "fine-grained" analysis to inform policy should be emphasized. There is a need to make an investment in developing research and analytical capacity. In the long run this means supporting the state in areas where it was always weakly developed such as data collection and census making - in order to make society more "legible" and therefore more governable.

Second, international policy needs to be informed by a regional perspective. As Clare Short, the former UK Minister for International Development has highlighted, there is a need for long-term, sustained engagement with Pakistan, India and the Central Asian republics. ${ }^{44}$ Conflict resolution in Kashmir for example is critical to stability within the region as a whole. International governments and development donors may need to think more carefully about the coherence of their policies from a conflict prevention and peacebuilding perspective. For example, unconditional military support for Central Asian regimes is likely to exacerbate the dynamics of conflict in the region which has led to the creation of movements like the IMU. Similarly IFI models of transition contribute to growing structural tensions. ${ }^{45}$ States in the region are continuing to pursue policies which create incentives for the growth of the war and shadow economies - including the tightening of borders which prevent legal cross-border trade, the repression of Islamic groups, human rights abuses, the cutting back of public services and privatization programs. In spite of their common history, infrastructure and culture, the trend within the Central Asian region has been to move away from integration, creating new tensions over resources, trade, immigration, and security policies.

Understandably, the Bonn Agreement is a state centric "road map" for peace. focusing on political, economic and security questions within Afghanistan. However, the "post-conflict" tag will remain only an aspiration if the regional dimensions of the conflict are ignored. A much bolder and ultimately more sustainable approach to peacebuilding would be to conceptualize it as a process of regional transformation rather than simply a case of putting Afghanistan "back on its feet." Particularly since the breakup of the Soviet Union, regional organizations in Central Asia have been weak. International actors can play a role in promoting and supporting regional cooperation in areas such as security, infrastructure, trade and development cooperation.

Third, a lesson from the past is that international neglect has been a significant factor in the development and expansion of the war economy. The obvious point to be made here is that there needs to be the right sort of engagement over an extended period of time from the international community. It is somewhat ironic given the past role of the international powers, but without an international guarantor - and this in effect 
means strong US backing for the United Nations - the negative dynamics of the war economy will reassert themselves: over decades rather than years. The concern now must be that attention has moved on to Iraq.

Fourth, we have emphasized that to address the war economy, Afghanistan needs a credible and effective state. A strong state is required to accelerate economic development and poverty reduction, to consolidate peace, to reduce the scope for extreme brutality and exploitation of social relations and to withstand the intrusive interests of regional powers. ${ }^{46}$ The danger of a "back to the future" scenario with a return to the warlord period is very real. International intervention may make this more or less likely. There is a need to develop coherent and complementary strategies which support the emergence of a legitimate state with the capacity to provide security, wealth and welfare. Short-term imperatives - for example the United States arming militias in the fight against terrorism or donors circumventing the state to fund their own "pet projects" -should not undermine this long-term objective. It is also important to note, that there is support from the Afghan population as a whole for a strong, centralized state. ${ }^{47}$

\section{Notes}

${ }^{1}$ This chapter is based on two fieldwork studies. The first, in 1997-99, on NGOs and complex political emergencies, was funded by DFID; the second in 2001 on the Afghan war economy was for the ODI. It draws primarily on two subsequent papers: Jonathan Goodhand, "Frontiers and Wars. A study of the opium economy in Afghanistan," Paper presented at the Canadian Social Science Research Council conference "Beyond Borders" (Vancouver, July, 2002), final draft 2003; and M. Bhatia and J. Goodhand with H. Atmar, A. Pain and M. Suleman, "Profits and Poverty: Aid Livelihoods and Conflict in Afghanistan," in Sarah Collinson et al., Power, Livelihoods and Conflict: Case Studies in Political Economy Analysis for Humanitarian Action, HPG Report 13 (February 2003).

${ }^{2}$ An important limitation which affects all researchers working on Afghanistan is the lack of reliable data. Even before the war, Louis Dupree wrote that statistics on Afghanistan were "wild guesses based on inadequate data," in Afghanistan (Princeton University Press 1980). This reflected the centralized but weak nature of the Afghan state. Mapping and conducting a census, the state's technologies of control which make society more legible and therefore more governable, were weakly developed. The problem of statistics was accentuated by what Dupree terms the "mud curtain," that was erected by villagers to keep an interfering state at bay - state officials visiting the countryside were met with evasion on questions related to land (because of taxation) and family members (because of conscription). Over two decades of conflict has compounded this problem and there has been virtually no long-term anthropological research inside Afghanistan during the war years, so that knowledge is partly stuck at pre-war levels. Finally there are inherent problems in obtaining any kind of meaningful data on the invisible and extremely sensitive nature of the opium economy, and statistics cited from secondary sources in this chapter should be treated as illustrative rather than authoritative. 
4 A. Pain and J. Goodhand, "Afghanistan: Current Employment and Socio-economic Situation and Prospects," International Labour Organisation, Infocus program on crisis response and reconstruction, Working Paper no. 8 (March 2002), 2.

5 Peter Wallensteen, Understanding Conflict Resolution. War, Peace and the Global System (London: Sage, 2002), 205.

${ }^{6}$ David Keen, "Incentives and Disincentives for Violence," in Mats Berdal and David Malone, eds., Greed and Grievance. Economic Agendas in Civil Wars, (Boulder, CO: Lynne Rienner, 2000).

${ }^{7}$ P. Le Billon, "The Political Economy of War: What Relief Workers Need to Know," ODI, Humanitarian Practice Network Paper no. 33, July 2000.

8 C. Nordstrom, "Shadows and Sovereigns," Theory, Culture and Society 17, no. 4 (2000), 35-54.

${ }^{9}$ See Rubin, 2000, Schetter $2001 \&$ Bhatia and Goodhand 2002.

${ }^{10}$ A group united by a norm of solidarity within the group and by competition with parallel groups. Rubin, The Fragmentation of Afghanistan, 346.

${ }^{11}$ D. Sagramoso, "The Illegal Proliferation of Small Arms and Light Weapons in Central Asia," in K. Pinnick, and J. Green, eds., Central Asia and the Post-conflict Stabilisation of Afghanistan (London: International Institute for Strategic Studies, 2002), 82.

${ }^{12}$ W. Maley, "Talibanization and Pakistan," in Talibanization: Extremism and Regional Instability in South and Central Asia (Brussels: CPN and Stiftung Wissenschaaft und Politik 2001).

${ }^{13}$ Mark Duffield, "Globalisation, Transborder Trade and War Economies," in Berdal and Malone, Greed and Grievance.

${ }^{14}$ M. Sedra "Challenging the Warlord Culture. Security Sector Reform in Post-Taliban Afghanistan" Paper 25, Bonn International Centre for Conversion, Bonn Germany, 2002:15.

15 A. Giustozzi, "Respectable Warlords? The Transition from War of all Against all to Peaceful Competition in Afghanistan," London School of Economics Research Seminar (29 January 2003), 7.

${ }^{16}$ Cited in UK, House of Commons, International Development Committee, “Afghanistan: The Transition from Humanitarian Relief to Reconstruction and Development Assistance. First Report of Session 2002-3," Report together with the proceedings of the Committee. Minutes of Evidence and Appendices ( 4 January 2003:31).

${ }^{17}$ Johnson et al., "Afghanistan's Political and Constitutional Development," 11. 18 Ibid.

19 J. Hirshleifer, The Dark Side of the Force. Economic Foundations of Conflict Theor! (Cambridge: Cambridge University Press, 2001).

${ }^{20}$ A Davis "How the Taliban Became a Military Force" in W. Maley (ed) "Fundamentalism Reborn"? Afghanistan and the Taliban" Vanguard Books, Lahore, Pakistan. 1998: 59. 
${ }^{21}$ UNODC, "The Opium Economy in Afghanistan. An International Problem" (United Nations, New York, 2003).

${ }^{22}$ Mansfield, "The Economic Superiority of Illicit Drug Production: Myth and Reality," Paper presented at the international conference on "Alternative Development in Drug Control and Cooperation," Feldafing, Germany (August 2001).

${ }^{23}$ UNODC, "Afghanistan, Strategic Study no. 9. Opium Poppy Cultivation in a Changing Policy Environment. Farmers' Intentions for 2002/3'UNODC, Kabul, Afghanistan, May. 2003).

${ }^{24}$ Rashid, "How the Taliban Became a Political Force," in Maley, ed., Fundamentalism Reborn? 72-89.

${ }^{25}$ M. Chingono, The State, Violence and Development: The Political Economy of War in Mozambique, 1975-1992 (Aldershot: Avebury, 1996).

${ }^{26}$ Goodhand, "From Holy War to Opium War? A Case Study of the Opium Economy in North Eastern Afghanistan," Central Asian Survey 19, no. 2 (2000), 265-280.

${ }^{27}$ D. Turtan, and P. Marsden, "Taking Refugees for a Ride? The Politics of Refugee Return to Afghanistan," Afghan Research and Evaluation Unit, Issues Paper Series, December 2002.

28 One ha. of opium requires as much as 350 person days compared to 41 for wheat. Women play a central role in minimizing labor costs. They are involved in planting, weeding, thinning, lacing the capsules, collecting gum, clearing fields, breaking the capsules and removing seed, cleaning the seed, processing byproducts such as oil and soap. Mansfield, "Alternative Development in Afghanistan: the Failure of the Quid Pro Quo," 10. Children also play a vital role. Attendance of boys at madrasas drops considerably during the weeding and harvesting season. Finally reciprocal labor (known as ashar) by families and friends plays an important role.

${ }^{29}$ Von der Schulenberg, "Peace in a Glasshouse."

${ }^{30}$ UNODC, "Afghanistan, Strategic Study No. 9."

${ }^{31}$ Turton and Marsden, "Taking Refugees for a Ride?"

32 Duffield, Global Governance and the New Wars. The Merging of Development and Security (London: Zed Books, 2001).

${ }^{33}$ A disturbing example of the latter is the young children acting as porters crossing the border at Torkham between Pakistan and Afghanistan carrying a range of commodities from scrap metal to drugs.

${ }^{34}$ Schetter, "The Bazaar Economy of Afghanistan," 114.

${ }^{35}$ Rashid, Taliban. Islam, Oil, 118.

${ }^{36}$ Nordstrom, "Shadows and Sovereigns," 37.

${ }^{37}$ Ibid. 
${ }^{38}$ Von der Schulenberg, "Illicit Opium Production in Afghanistan."

39 Paul Collier, "Doing well out of war. An economic perspective," in Berdal and Malone, Greed and Grievance, 91-112.

40 This point draws on Mark Bradbury's analysis in relation to Somalia. M. Bradbury "Living with Statelessness: The Somali Road to Development," Journal of Conflict, Security and Development 3, no. 1 (April 2003).

${ }^{41}$ cited in House of Commons, International Development Committee, "Afghanistan.": 6

${ }^{42}$ House of Commons, International Development Committee, "Afghanistan."

${ }^{43}$ Turton and Marsden, "Taking Refugees for a Ride?"

44 Cited in UK, House of Commons, International Development Committec, "Afghanistan: The Transition from Humanitarian Relief to Reconstruction and Development Assistance. First Report of Session 2002-3," Report together with the proceedings of the Committee, Minutes of Evidence and Appendices (14 January 2003).

45 Tony Vaux and Jonathan Goodhand, "Disturbing Connections: Aid and Conflict in Kyrgyzstan”, Conflict Assessments 3, Centre for Defence Studies, King's College, London (July 2001)

${ }^{46}$ C. Cramer, and Jonathan Goodhand, "Try Again, Fail Again, Fail Better? War, the State, and the Post-conflict Challenge in Afghanistan," Development and Change 33, no. 5 (2002), 904.

${ }^{47}$ Johnson et al., “Afghanistan's Political and Constitutional Development," 19.

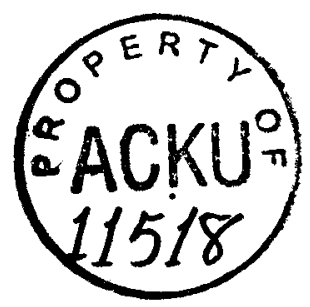

